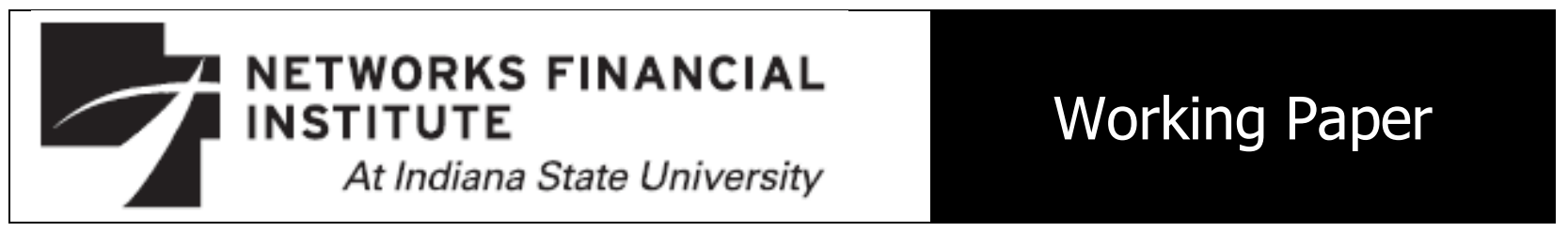

2011-WP-16

July 2011

\title{
The Relative Performance of Debt-restricted Real Estate Investment Trusts (REITs): Does Faith Matter?
}

\section{Kabir Hassan, Yasser Alhenawi and Hesham Merdad}

Abstract: Ibrahim \& Ong (2008) use operational restrictions of Islamic Investment Guidelines and conduct a thought experiment on Real Estate Investment Trusts (REITs) under restricted and non-restricted schemes. We use financial restriction and reach somewhat different results. Compliant REITs underperform non-compliant REITs in equally-weighted portfolios. However, the results are inversed in value-weighted portfolios. In the latter case, compliant REITs outperform non-compliant REITs and provide a less volatile investment vehicle. More interestingly, during the recent financial crisis, compliant REITs generated higher gains in equally-weighted portfolios and lower losses in value-weighted portfolios. Yet, there is no difference between the restricted and non-restricted portfolios when broader economic factors are included in the research.

About the Author: Dr. Kabir Hassan is a professor at the University of New Orleans and also holds a visiting research professorship at Drexel University, Philadelphia. He is a financial economist with consulting, research and teaching experiences in development finance, money and capital markets, corporate finance, investments, monetary economics, macroeconomics and international trade and finance. He has published five books, over 70 articles in refereed academic journals and has presented over 100 research papers at professional conferences globally. Yasser Alhenawi is an Assistant Professor of Finance in the Schroeder Family School of Business Administration at the University of Evansville. Hesham Merdad is a doctoral student at the University of New Orleans.

Keywords: Real Estate Investment Trusts, Ethical Investing, Carhart Four-Factor Model.

JEL Classification: G12, G20, G23.

The views expressed are those of the individual author and do not necessarily reflect official positions of Networks Financial Institute. Please address questions regarding content to M. Kabir Hassan at mhassan@uno.edu. Any errors or omissions are the responsibility of the author.

NFI working papers and other publications are available on NFI's website (www.networksfinancialinstitute.org). Click "Thought Leadership" and then "Publications/Papers." 


\section{INTRODUCTION}

In 2009-10, the world suffered economic turbulence emanating from the financial meltdown that started in September 2008 and stormed through financial markets and institutions globally. Excessive use of debt has been identified as a major contributor, among other factors, to the financial crisis. In this paper, we investigate performance of investment instruments under two different borrowing approaches. However, instead of generating an arbitrary set of restrictions, we elect to use an existing borrowing scheme offered by Islamic investment principles. Thus, this paper also serves as an empirical test of the performance of Islam-compliant investment instruments. Islamic investment guidelines contain certain operational and financial restrictions. We follow the approach of Ibrahim and Ong (2008) to screen instruments based on their compliance with Islamic investment guidelines. However, while Ibrahim and Ong (2008) apply operational screening (a so-called "moral filter"), we apply financial screening (debt usage). We believe that this screening is timely, given the current academic and practical debate on the wisdom of using excessive debt financing.

We use Islamic investment guidelines as a framework to impose various debt and interest usage restrictions on portfolios of Real Estate Investment Trusts (REIT). We have chosen REIT in particular to benefit from a growing stream of literature on Islamic REITs (referred to as IREITs). I-REITs attract all investors and issuers regardless of race and religion ${ }^{1}$ (Dusuki, 2007). Further, I-REITs have their features and advantages that meet specific investment interests and needs. For instance, higher dividend yield and potential hedge against inflation (Lin \& Yung,

\footnotetext{
${ }^{1}$ Confinement to Islamic commercial jurisprudence influences I-REIT at the operational level with almost no restrictions applicable to investors (unit holders).
} 
2006), and more stable income ${ }^{2}$ and tax incentives (Chan, Leung, \& Wang, 2005) make I-REITs appeal to a certain clientele of investors, such as pension funds and retirees (Lin \& Yung, 2006;

Ghosh, Nag, \& Sirmans, 1999).

We synthesize a sample of Islam-compliant REITs and compare their performance to conventional REITs. Unlike Ibrahim and Ong (2008), however, we apply the financial restrictions of Islamic investment guidelines. We create four portfolios based on compliance (compliant, non-compliant) and weighing criteria (equally-weighted and value-weighted). Then we track their performance over the period 1990-2009. We calculate average and cumulative returns and Jensen's alpha with different capital asset pricing models. In contrast to Ibrahim and Ong (2008), we find that compliant REITs outperform non-compliant REITs in value-weighted portfolios (but not in equally-weighted portfolios) over the study period. Further, compliant REITs outperform non-compliant REITs in both value-weighted and equally-weighted portfolios during the recent financial crisis. We also find evidence that compliant REITs are less volatile than non-restricted REITs. However, consistent with Ibrahim and Ong (2008), we find that when market risk and other risk factors are accounted for, the restricted REITs do not behave significantly different from non-restricted REITs.

The paper is organized in five sections. In section II, we provide a primer on Islamic investing guidelines and we compare REITs to I-REITs. Section III presents a review of the extant empirical literature on conventional REITs and Islamic REITs. Section IV provides the

\footnotetext{
${ }^{2}$ The fund manager is required to distribute its income in the form of dividend in order to enjoy tax incentives. For instance, REITs are required to pay out a minimum amount (in most cases it is at least minimum 90 percent) of their income as distribution to qualify for tax transparency in Malaysia (Treasury Malaysia, 2006) and the USA (Feng, Ghosh,\& Sirmans, 2007).
} 
data and description of methodology following Ibrahim and Ong (2008). Section V presents empirical findings and concludes the paper.

\section{Literature Review of Islamic Investing}

In the last decade, modern economies witnessed substantial growth interrupted by several economic and financial crises occurring at an increasing frequency. By late 2008, the U.S. financial system was on the verge of collapsing. The severity of the crisis called for not only immediate corrective movements, but also for a deeper thinking of the underlying concepts and postulates of the current financial system. Specifically, the long-celebrated notion of selfcorrecting free markets came under deep scrutiny. President Nicolas Sarkozy of France and Prime Minister Angela Merkel of Germany suggested "re-thinking capitalism." Consequently, it is legitimate to investigate features and concepts of other economic and financial systems. In this paper, we focus on a unique subset of Socially Responsible Investment (SRI): Islam-compliant investment. We have made this choice because Islamic Investment Guidelines are particularly marked with restrictions on the excessive use of debt, which has been accused of being a major reason for the current financial crisis.

\subsection{Principles of Islamic Investing}

The market for Islam-compliant investments is growing rapidly. Muslims represent approximately one-fifth of the world's population. Some sources estimate Muslims' investments to be between USD 250 billion and USD 1 trillion (Chow, 2006), growing by 15 percent annually in a market that is not fully exploited ${ }^{3}$ (Hassan, 2002). According to a McKinsey \&

\footnotetext{
${ }^{3}$ For instance, when compared to the mutual fund industry at large, Islamic mutual funds have been around for less than a decade and are still in their infancy stage of growth and development (Girard \& Hassan, 2008).
} 
Company report, "Islamic finance is the new force in the financial market place." Islamic banking grew at a rate of 15 percent in mid-1990s (Abdul Halim \& Norizaton Azmin, 2001), making it one of that decade's fastest growing niche in global financial markets (Aggarwal \& Yousef, 2000).

In essence, Islamic alternatives to traditional investment tools have been driven by the fact that the latter do not conform to the Islamic jurisprudence (Shariah) standards (Usmani, 2002). The Muslim faith dictates "no pain, no gain," implying that there should be proportionality between risk and return, one of the fundamental principles of modern finance as well. This is not the case in interest-dominated investments (Aggarwal and Yousef, 2000). The subtle, yet important, issue here is the concept of fixed-interest, which is prohibited. (More details are available in the next section.) In addition, there is a desire for investments in activities that are morally purified. Thus, some operational restrictions apply besides financial ones. The finance literature has documented several Islamic investment guidelines (see in particular, ElGamal, 2000; Hassan, 2002; Girard \& Hassan, 2008; Ibrahim \& Ong, 2008; Dusuki, 2007). For the purpose of this paper, we categorize these guidelines into two major categories: (1) financial and (2) operational.

Financial guidelines pertain to sources of income, sources of funds, and insurance. First, Islamic business and trade guidelines prohibit fixed interest income. ${ }^{4}$ Practically, it is not permissible to invest in securities of companies with gross interest-bearing debt to total assets that exceeds 33 percent (Girard \& Hassan, 2008). Similarly, it is not permissible to invest in securities of companies with interest income exceeding 5 percent of total revenues (Ibrahim \&

\footnotetext{
${ }^{4}$ Called "riba" in Arabic language.
} 
Ong, 2008). Finally, accounts receivable and cash accounts may not exceed 50 percent of total assets (Ibrahim \& Ong, 2008).

On the operational dimension, Islamic principles prohibit gambling and pure games of chance, ${ }^{5}$ as well as selling something that is not owned or that cannot be described in accurate detail in terms of type, size, and amount ${ }^{6}$ (El-Gamal, 2000). Accordingly, short-selling and intensive speculation activities are prohibited. Also prohibited is the production or distribution of non-permissible products such as alcohol, tobacco, pork, and arms. Finally, Islamic principles prohibit investing in non-productive and/or potentially harmful gaming and entertainment activities such as gambling and prostitution. Nevertheless, the final say on what constitutes a prohibited investment rests in the arm of a "Shariah Board." For instance, the board may allow investment in partially "contaminated" ventures. ${ }^{7}$

\subsection{Real Estate Investment Trust (REIT) vs. Islamic Investment Trust (I-REIT)}

The REITs are structured to provide investors with an investment instrument in real estate similar to mutual funds in stocks. REIT funds invest their portfolios in listed securities of real estate companies that own and operate real estate properties. ${ }^{8}$ REIT funds enjoy reduced or eliminated corporate income taxes. In return, REITs are required to distribute 90 percent of their income, which may be taxable in the hands of the investors. Investors interested in the real estate industry find REITs attractive because of: (1) lower diversification costs, (2) investment experience, (3) lower information costs due to economies of scale, and (4) greater security.

\footnotetext{
${ }^{5}$ Called "maysir" in Arabic language.

${ }^{6}$ Called "gharar" in Arabic language.

${ }^{7}$ It may require, however, income to be cleansed or purified by donations to charities or by "zakat" [a form of charity paid (to the poor) from personal wealth exceeding a minimum amount (called nisab) held idle for one lunar year].

${ }^{8}$ The requirements on the amount of a fund invested in real estate vary across countries (75 percent in the United States, 70 percent in Korea and Singapore, 50 percent in Malaysia).
} 
Islamic Real Estate Investment Trusts feature the same underlying investment logic and principles as non-Islamic REIT's with a few, yet critical, differences. The main difference is the requirement of strictly observing Islamic business and investment guidelines set forth by Islamic jurisprudence. The Shariah-compliant assessment is undertaken by a Shariah committee or advisors, whose action and responsibilities resemble those of a trustee in a non-restricted REIT.

In the real estate business, however, it is very common to face cases of mixed activities, i.e., permissible and non-permissible activities occurring together. Dusuki (2007) explains principles that govern to the extent to which financial rules are to be enforced. First, a REIT must avoid non-permissible (Haram) rental activities such as interest-based financial services, production or distribution of non-permissible products (alcohol, tobacco, pork), and non-permissible gaming and entertainment activities (gambling and prostitution). Second, in the case of mixed activities, rental from non-permissible activities must not exceed 20 percent of total turnover of the Islamic REIT. ${ }^{9}$ Third, it is not permitted to acquire real estate in which all tenants operate nonpermissible activities, even if all tenants pass the ratio criteria cited above. Fourth, it is not permitted to accept a new tenant when it is obvious that she is involved in impermissible activities (casinos for instance). Fifth, an I-REIT must use cooperative insurance ${ }^{10}$ schemes to insure real estate, if they exist. Finally, an I-REIT is permitted to participate in forward sales or purchases of currency and is encouraged to deal with Islamic financial institutions.

\footnotetext{
${ }^{9}$ The ratio could be calculated based on usage of space, hours of service, or other methods. For instance, a 10,000 square foot supermarket may allocate up to 2,000 square feet for alcohol sales activities.

${ }^{10}$ Called "Takaful" in Arabic language.
} 


\section{Review of the Extant Empirical Literature}

Very little literature and research have been done on I-REITs. Yet, there exists some research on related instruments: Socially Responsible Investments. SRIs are not identical to I-REITs but carry the same philosophy of avoiding certain investment ventures, despite how lucrative they are, if they are deemed unethical or harmful to the society. There is no consensus on whether adhering to ethical standards has an impact on return. Some research found evidence of lower return (Girard, Rahman \& Stone, 2007; Walley \& Whitehead, 1994). Others found no significant difference between socially responsible and conventional investment instruments (Schroder, 2004; Bauer, Koedijk \& Otten, 2005; Bauer, Otten, \& Rad, 2006). Yet, others found that improved social or environmental performance leads to improved efficiency and/or more opportunities (Porter \& van der Linde, 1995) and improved financial performance (Orlitzky, Schmidt, \& Rynes, 2003).

Islamic investment in general, however, has obtained increasing attention recently. Hassan (2002) employed serial correlation, variance ratio, and Dickey Fuller tests to examine the market efficiency of the Dow Jones Islamic Market (DJIM) over the period 1996-2000 and finds evidence of normal distribution and efficiency. He also examined anomalies and volatility of the DJIM returns. The results showed no anomaly effects and a significant positive relationship between conditional volatility and DJIM equity index returns. Girard and Hassan (2008) examined Islamic and non-Islamic Financial Times and London Stock Exchange (FTSE) indexes from January 1999 to December 2006 and find no convincing difference in performance.

Hakim and Rashidian (2004a and b) employ a co-integration and causality analysis and find no correlation and no causality effect between the DJIM and the Wilshire 5000 Index, or the 
three month Treasury bill over the time period 1999-2002. They conclude that the Islamic index possesses unique risk-return characteristics unaffected by the broad equity market. They use a capital asset pricing model (CAPM) and show that the DJIM has done well compared to the Dow Jones World Index (DJW) but underperformed the Dow Jones Sustainability World Index (DJS) or green index.

Hussein (2005) conducted a comprehensive study of the accurate performance of each Islamic index by capturing the effects of industry, size, and economic conditions on DJIM returns over the period 1996-2003. He finds that Islamic indexes provide investors with positive abnormal returns in bull markets, but they underperform their non-Islamic index counterparts in bear markets. He argues that positive abnormal returns are driven by investing in small size, basic material, consumer cyclical, industrial, and telecommunication firms.

Elfakhani, Hassan and Sidani (2005) consider an overall sample of 46 Islamic mutual funds and find that the number of outperforming funds ranges between 29 funds (63 percent) and 11 funds (24 percent), depending on the performance measure used and market benchmark. They also find that four of the eight fund categories outperform their benchmarks regardless of what performance measure is used. In addition, using the analysis of variance (ANOVA) statistical test, they show that no statistically significant disparity exists for the performance of the Shariahcompliant funds compared to all non-Shariah compliant funds.

Hassan and Tag el-Din (2005) adapt duration dependence tests to analyze Islamic mutual funds of the DJIM. They use both weekly and monthly data of the DJIM and Amana Income (AMANX) and Amana growth (AMAGX) funds to test for the speculative bubbles in these markets. Their results show that none of the weekly and monthly returns of AMANX, AMAGX, 
and the DJIM show statistically significant evidence of speculative bubbles during various sample periods.

Fikriyah, Hassan, and Shamsher (2007) use 14 Islamic funds and 51 conventional mutual funds in the Malaysian capital market (Jan 1992 - Dec 2001). They use the Sharpe index, the adjusted Sharpe index, Jensen's alpha, Modigliani measure, and timing and selectivity ability and find that Islamic funds performed better than the conventional funds during a bearish market, while conventional funds performed better than Islamic ones during a bullish market. Including Islamic mutual funds in a portfolio helps hedge the downside risk in adverse economic conditions. Islamic and conventional funds have a diversification level that is less than 50 percent the diversification level of the market index proxied by the Kuala Lumpur Composite Index (KLCI). They conclude that there is poor selection and timing performance in both Islamic and conventional mutual funds.

Ibrahim and Ong (2008) investigate the cost of compliance with Islamic investment principles using REITs as an example of Islamic investment tool. They compare synthetic compliant REIT portfolios with unconstrained REIT portfolios, indexes, and real estate mutual funds (REMF). They find evidence of lower return but argue that this does not mean that I-REIT portfolios necessarily underperform relevant indexes when relevant risk factors are considered.

\section{Methodology and Data}

\subsection{The Simulation Approach of Ibrahim \& Ong (2008)}

In this paper, we adopt a research design that resembles Ibrahim and Ong (2008) in terms of pursuing an experimental design to obtain relevant data. We, however, apply a financial filter while they apply an operational (sectoral) filter. They screen all listed REIT in the U.S. market 
for conformity with Islamic investment guidelines. They use only what we call in this paper "operational" screening and opted not to impose financial screening. They obtain a sample of 88 strict I-REITs (exclude all hotel, retail and diversified REITs) and 122 less-restrictive (LR) IREITs (ancillary activities comprise less than 20 percent of total activity ${ }^{11}$ ).

Using cumulative performance observations, they find evidence that both I-REITs and LR I-REITs underperform the benchmarks on both equal- and equity-weighted portfolios. They also find that strictly-restricted I-REITs tend to underperform LR I-REITs. They conclude that less restrictive compliance requirements tend to bring about higher cumulative returns. However, when they use the Sharpe Ratio, the picture becomes somewhat blurry because the difference between I-REITs, LR I-REITs, and the benchmark become less pronounced in the equallyweighted portfolio. (The value-weighted portfolio still shows I-REITs underperform benchmarks.)

Second, they test for the significance of Jensen's alpha using (1) CAPM and (2) Fama and French three-factor model (Fama and French 1993, 1995 and 1996a and b) with Carhart's (1997) momentum factor (only the second test results were reported). They use a set of benchmarks including:

- Market return proposed by Fama and French (1993, 1995 and 1996a and b);

- EQREIT index (measure performance of REITs that are part of the national association of REITs); and

\footnotetext{
${ }^{11}$ Proxied by space, which is one of the accepted proxies that include time, income, and combinations.
} 
- Wilshire Real Estate Securities (WRES) index, which is a value-weighted index of publicly traded real estate securities.

They reach somewhat contradicting results. On one hand, Jensen's alpha is negative and insignificant for market-weighted portfolios. On the other hand, Jensen's alpha is positive and significant for the equally-weighted portfolios. They conclude that there is no evidence of IREITs underperformance when they control for other risk factors.

Third, they compared I-REIT performance to a different benchmark, which is RMEF (a monthly return on a portfolio of 185 real estate mutual funds using Center for Research in Security Prices (CRSP) data from January 1996 through April 2006). They reach similar conclusions, i.e., I-REITs underperform the benchmark and the difference is more pronounced in the case of market-weighted portfolios. When they account for other risk factors, the difference between I-REIT portfolios and the benchmark becomes insignificant.

\subsection{Our Data, Methodology, and Results}

We collect quarterly data on 163 active REIT's (Standard Industrial Classification code 6798) from Compustat databases over the period 1990Q1-2009Q4. In each quarter (there are 80 quarters) we obtain the REIT's total assets, long-term debt, quarter closing price, and market value. We eliminate all missing or irregular entries (such as negative values for stock price and zeros for total assets). We calculate the debt ratio as long-term debt divided by total assets. Since this variable is the main selection filter (as will be shown later), we eliminated the upper and lower 0.5 percent outliers. Table 1 below shows the descriptive statistics of our sample. 


\section{Table 1 Variables Descriptive Statistics}

\begin{tabular}{c|ccc|}
\cline { 2 - 4 } & Debt Ratio & $\begin{array}{c}\text { Price } \\
\text { (USD) }\end{array}$ & $\begin{array}{c}\text { Market Capitalization } \\
\text { (Million USD) }\end{array}$ \\
\hline Mean & 0.47948 & 23.61666 & 1178.63828 \\
Std Dev & 0.19644 & 23.16358 & 2109.44201 \\
Minimum & 0.010073 & 0.039000 & 0.14640 \\
Maximum & 0.95085 & 419.64999 & 24851.80469 \\
Median & 0.49115 & 19.80500 & 490.12221 \\
$\mathbf{1}^{\text {st }}$ Quartile & 0.37003 & 10.13750 & 140.48590 \\
$\mathbf{3}^{\text {rd }}$ Quartile & 0.60992 & 30.80000 & 1297.52463 \\
IQ Range & 0.23989 & 20.66250 & 1157.03873 \\
\hline
\end{tabular}

Our final sample includes 7,870 observations of 163 REITs in the period 1990Q12009Q4 (80 quarters). The average debt ratio of all REITs in all time points (quarters) is about 48 percent, with a standard deviation of about 19.6 percent. The highest and lowest debt ratios in the sample are about 95 percent and 1 percent, respectively. About 50 percent of all data points fall between 37 percent and 61 percent. The average stock price is about $\$ 23.61$, with a minimum of about $\$ .04$ and a maximum of about $\$ 420$. Average market capitalization is about $\$ 1178.7$ million with a minimum and maximum of about $\$ 24,851$ million and $\$ 0.146$ million, respectively.

We split our REIT sample into two portfolios: one is restricted REITs (Shariahcompliant) and the other is non-restricted REITs (non-Shariah compliant). We use gross interestbearing debt as a percentage of total assets as the filtering criterion. Our filtering threshold is 33 percent (the maximum debt ratio permitted by Islamic investing principles ${ }^{12}$ ). In this regard, our work is different from Ibrahim and Ong (2008), who apply operational restrictions.

\footnotetext{
${ }^{12}$ In an earlier version of this paper, we used two additional criteria. Namely, accounts receivables as a percentage of total assets is less than 50 percent and interest expenses as a percentage of total expenses is less than 5 percent. These two criteria, along with debt ratio used in this version, constitute the three financial filters that distinguish
} 
We assume that a hypothetical investor is composing Shariah-compliant equallyweighted and value-weighted portfolios of available REITs. She selects only REITs that pass the criterion of having less than 33 percent for the debt ratio. Every quarter, she screens available REITs for compatibility with this criterion and re-composes her portfolios accordingly. The frequency of data used in this study is slightly lower than other studies [weekly and monthly as in Hassan and Tag el-din (2005) and monthly in Hassan (2002)]. The rationale of using quarterly updating is that our criteria are derived from balance sheet data available on a quarterly basis only. We will show below that increasing the updating frequency from quarterly to monthly does not change the overall results we obtain.

For the purpose of comparison, we form two non-restricted portfolios (one equallyweighted and one value-weighted) composed of all the REITs that do not pass as compliant in each quarter. Figure 1 below shows the number of REITs available in each quarter (quarterly sample size), REITs that pass as Shariah-compliant, and REITs that do not, across time horizon of this study. It also shows the number of REITs that are non-existent in certain quarters due to missing data.

Shariah-compliant investment vehicles from non-complaint ones. These two criteria, however, may be debated. First, it may be argued that these three criteria are highly correlated. Further, using these two additional criteria would not add any additional restriction. In each quarter, a certain number of REITs (16 to 32, as will be shown later in this paper) would pass as Shariah-compliant using the debt ratio criterion only. Imposing the two other criteria, along with the debt ratio criterion, lowers this number in 6 quarters only (out of 80 quarters) by one REIT in each quarter. In short, adding these two criteria did not significantly change our screening output. On the other hand, imposing these two criteria would reduce the sample size by almost 50 percent. This is because REITs' interest expenses and receivables data are not complete in Compustat. We find that it is not wise to reduce our sample size by half to ensure availability of data for criteria that are questionable (highly correlated with debt ratio) and add very little to the rigor of restriction (reduces number of compliant REITs by one in 6 quarters out of 80). 
Figure 1 Number of REITs in the Compliant and Non-Compliant Portfolios across Time

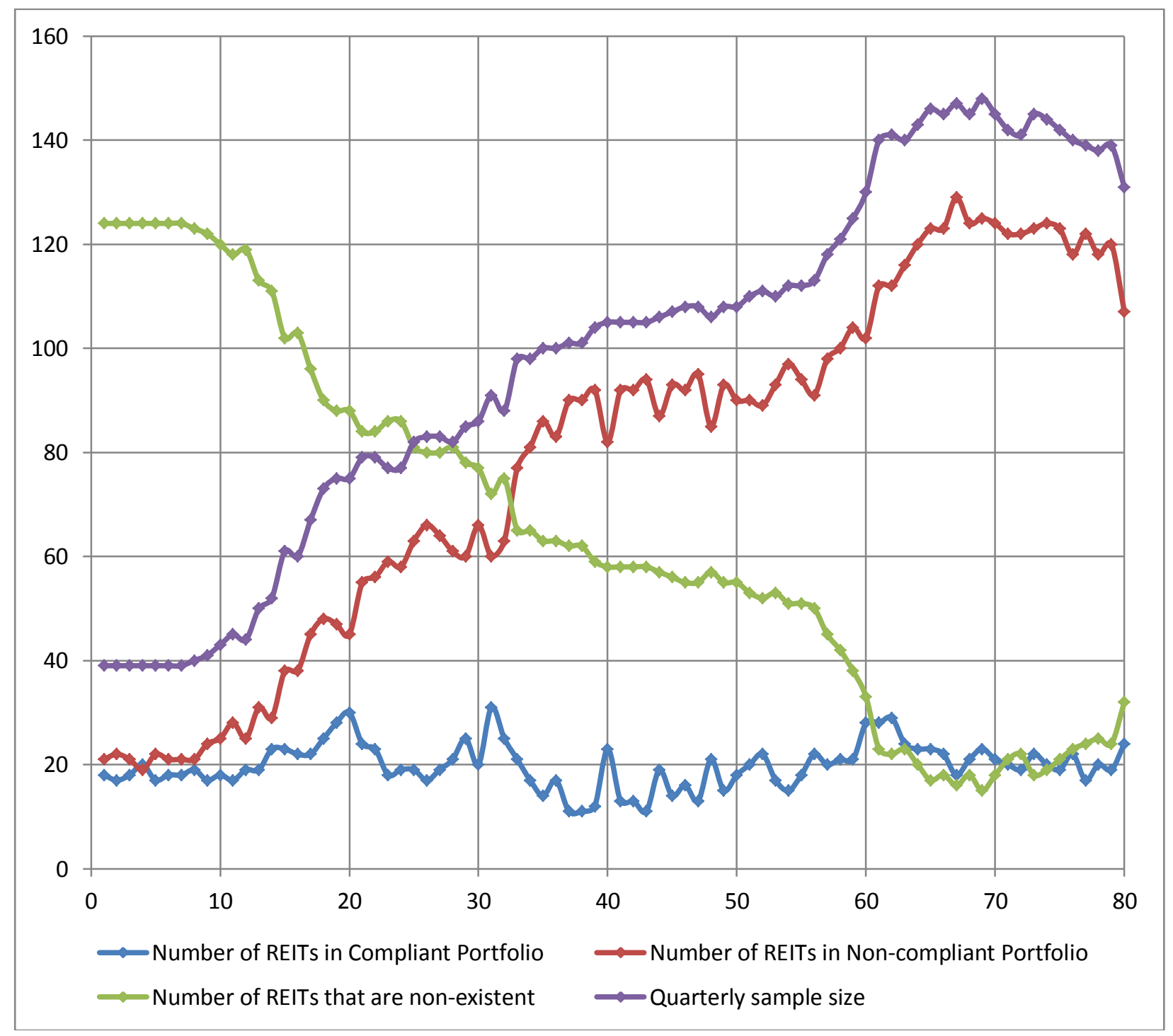

The figure shows how 163 REITs included in this study are distributed as compliant and non-compliant portfolios over time. We start with a sample of 39 REITs in 1990Q1 where 18 are compliant REITs and 21 are non-compliant. Over time, the sample increases as more data become available every quarter. However, we notice that most of the sample size increase goes to non-compliant REITs (more than 33 percent of debt). At the end of the analysis period, fourth 
quarter of 2009, we have 24 REITs that pass as compliant and 107 that do not and a total sample size of 131 REITs.

The four portfolios formed and tracked in this paper are: 1) REW: restricted equallyweighted 2) NEW: non-constrained equally-weighted 3) RVW: restricted value-weighted 4) NVW: non-constrained value-weighted. In the equally-weighted portfolio REW, we assume that our investor invests equally in all the RIETs that pass as Shariah-compliant (and we do the same in the non-compliant portfolio NEW). In the value-weighted protfolio $\mathbf{R V W}$, we assume that our investor distributes her investment over compliant REITs in such a way that each REIT receives a fraction of the total investment that equals the percentage of that REIT's market value to all compliant REITs' market value in each quarter (and we do the same in the non-compliant portfolio NVW).

We start with an initial investment of \$1 in each portfolio in the first quarter of 1990. Then we update each portfolio quarterly by including REITs that do (do not) comply in the compliant (non-compliant). We report the overall value of each portfolio; then we calculate the quarterly return and the analysis period cumulative return. The following figure shows the quarterly return of the four portfolios created. 
Figure 2 - Quarterly Returns of the Four Portfolios

Equally-weighted portfolios

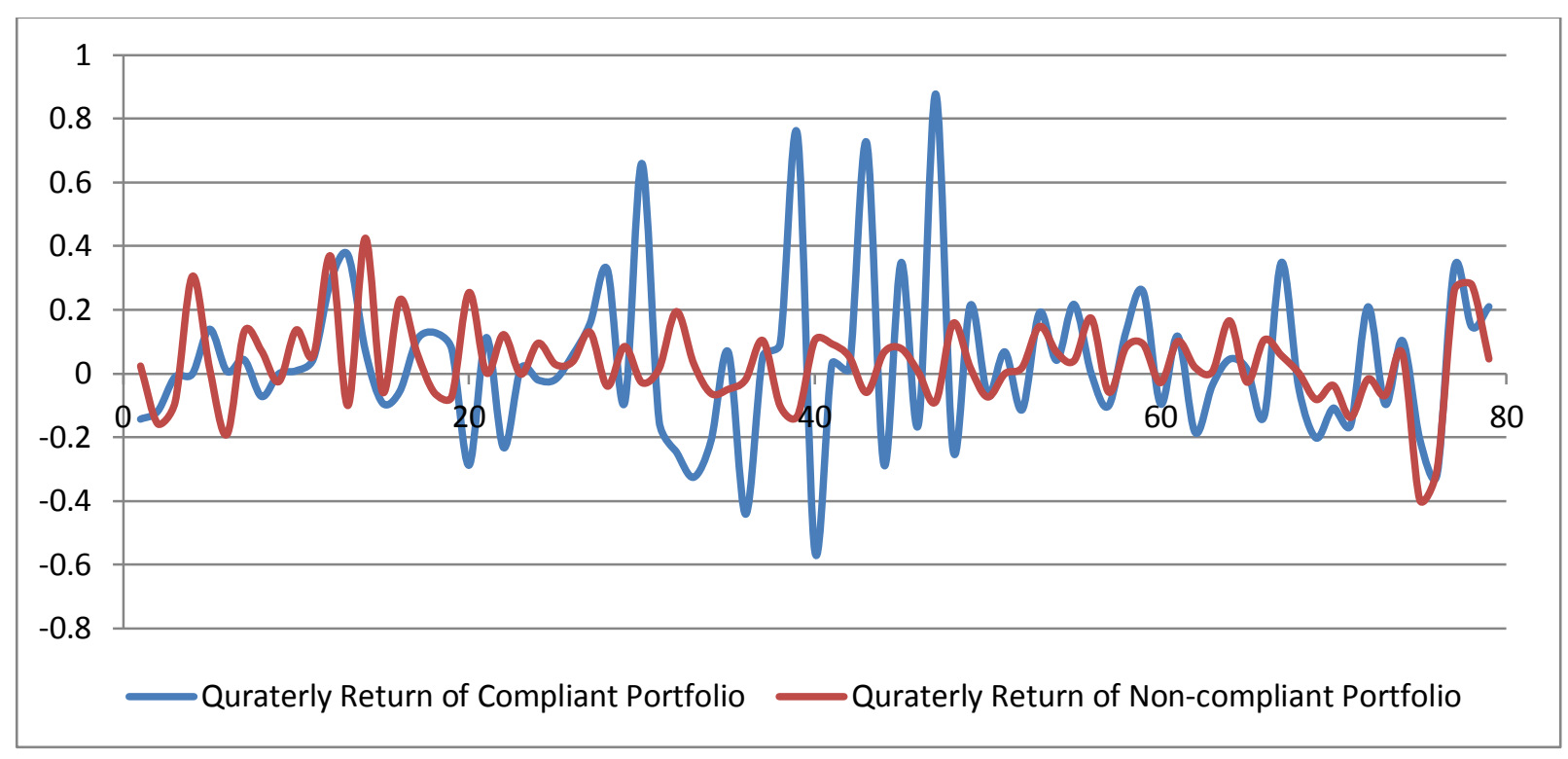

\section{Value-weighted portfolios}

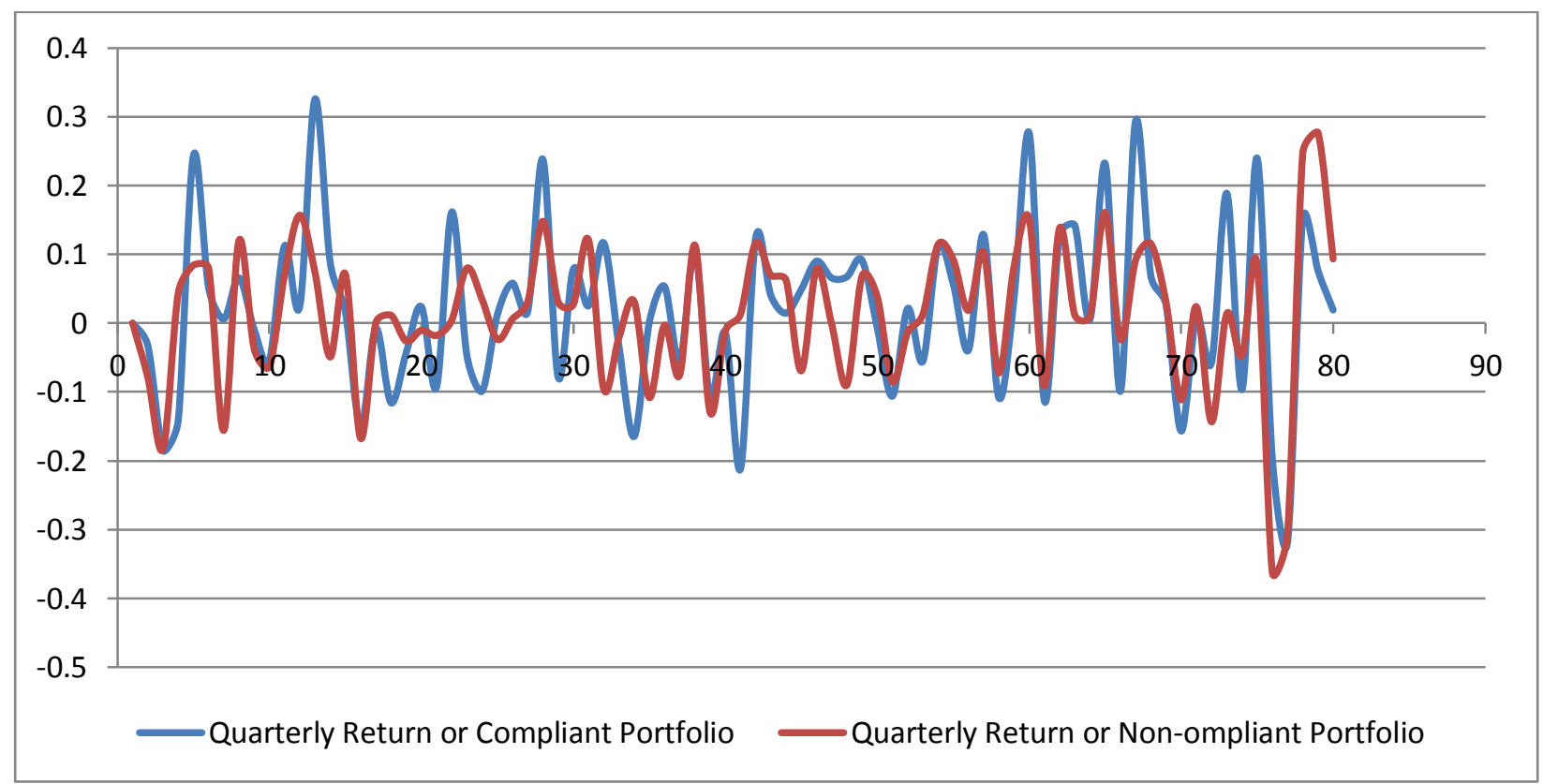

The following table illustrates the four portfolios created and descriptive statistics of their quarterly returns. The average quarterly return on the REW portfolio is about 3.27 percent while the average quarterly return on the NEW portfolio is 3.33 percent. The difference between the 
two is only 6 basis points per quarter, equivalent to about .32 percent annually in favor of the non-compliant portfolio. In the value-weighted portfolios, the difference is much larger. The RVW portfolio realized an average quarterly return of 1.97 percent compared to 1.23 percent in the NVW portfolio. The difference is about 66 basis points, equivalent to about 2.64 percent annually in favor of the compliant portfolio. Looking at other descriptive statistics, coefficient of variation in particular, we notice that volatility of the REW portfolio is almost double that of the NEW portfolio. However, the RVW portfolio is slightly less volatile than the NVW portfolio. We conclude that when equal weighting is used, a restricted portfolio performs worse in both average return and volatility. In value-weighted portfolios, restricted REITs perform better in both average return and volatility. This is a not consistent from Ibrahim and Ong (2008) findings of sub-performance of Shariah-compliant REITs.

Table 2 - Portfolios Descriptive Statistics

\begin{tabular}{c|cc|cc|} 
& \multicolumn{2}{|c|}{ Equally-weighted Portfolio } & \multicolumn{2}{c|}{ Value-weighted Portfolio } \\
\cline { 2 - 5 } & $\begin{array}{c}\text { Restricted } \\
\text { Portfolio }\end{array}$ & $\begin{array}{c}\text { Non-restricted } \\
\text { Portfolio }\end{array}$ & $\begin{array}{c}\text { Restricted } \\
\text { Portfolio }\end{array}$ & $\begin{array}{c}\text { Non-restricted } \\
\text { Portfolio }\end{array}$ \\
\hline Mean & REW & NEW & RVW & NVW \\
\hline Std Dev & 0.032710 & 0.033317 & 0.019710 & 0.012266 \\
Coefficient & 0.24638 & 0.13106 & 0.12241 & 0.10546 \\
of Variation & 7.545 & 3.927 & 6.211 & 8.598 \\
Minimum & -0.55604 & -0.39675 & -0.31852 & -0.36251 \\
Maximum & 0.87758 & 0.42510 & 0.32581 & 0.27706 \\
Median & 0.011505 & 0.021467 & 0.018109 & 0.013314 \\
$\mathbf{1}^{\text {st Qtr }}$ & -0.11211 & -0.046678 & -0.055625 & -0.045324 \\
$\mathbf{3}^{\text {rd } \mathbf{Q t r}}$ & 0.13005 & 0.099704 & 0.089567 & 0.081976 \\
IQ Range & 0.24216 & 0.14638 & 0.14519 & 0.12730 \\
\hline
\end{tabular}


We create four different portfolios based on compliance with Shariah investment rules (Restricted, Non-restricted, and Free) and based on portfolio weighing (equally-weighted and value-weighted). The four portfolios are: 1) REW a restricted (Shariah-compliant REITs) equally-weighted portfolio 2) NEW an non-constraind (all but the Shariah-compliant REITs) equally-weighted portfolio 3) RVW restricted (Shariah-compliant REITs) value-weighted portfolio 4) NVW a non-constrained (all but the Shairah-compliant REITs) value-weighted portfolio.

In the following, we conduct more sophisticated tests of performance. We start with buy-andhold return (BHR); then we use the Jensen's alpha measure of performance with various versions of CAPM.

\section{i) Buy-and-hold Returns}

We start our analysis of the historical performance by calculating the buy-and-hold return of the four portfolios over the study period. We calculate BHR as follows:

$$
B H R_{i, t}=\left[\left(\prod_{t=1}^{t}\left(1+R_{i, t}\right)\right)-1\right]
$$

Where:

$B H R_{i, t} \quad: \quad$ buy-and-hold return for portfolio $i$ in period $t$

$t=1 \quad: \quad$ indicates the first quarter of the study period

$R_{i, t} \quad$ : $\quad$ return for portfolio $i$ in period $t$

The results are reported in the table below. The BHR analysis confirms our earlier finding that the restricted equally-weighted portfolio underperforms the non-restricted one, but the restricted value-weighted portfolio outperforms the non-restricted one. If our hypothetical investor had invested one dollar in the 1990Q1 in each of the four portfolios, she would end up 
with $\$ 1.5$ in the REW portfolio, \$7.136 in the NEW portfolio, \$2.675 in the RVW portfolio, and $\$ 1.667$ in the NVW portfolio. This result, coupled with the earlier results in Table 2 above, indicates that portfolio weight composition is an important determinant of success in such investment. The investors cannot earn the excess return generated by Shariah-compliant REITs unless their REITs' weights are proportional to their market capitalization values.

Table 3 Performance of Portfolios Measured by BHR (1990Q1-2009Q4)

\begin{tabular}{|c|c|c|c|c|c|c|}
\hline & & \multicolumn{2}{|c|}{ Equally-weighted Portfolio } & & \multicolumn{2}{|c|}{ Value-weighted Portfolio } \\
\hline & & $\begin{array}{c}\text { Restricted } \\
\text { Portfolio }\end{array}$ & $\begin{array}{c}\text { Non- } \\
\text { restricted } \\
\text { Portfolio }\end{array}$ & & $\begin{array}{c}\text { Restricted } \\
\text { Portfolio }\end{array}$ & $\begin{array}{c}\text { Non- } \\
\text { restricted } \\
\text { Portfolio }\end{array}$ \\
\hline & & REW & NEW & & RVW & NVW \\
\hline $\begin{array}{c}\text { Initial } \\
\text { Investment } \\
\text { Value } \\
(\$)\end{array}$ & 1990Q1 & 1 & 1 & 1990Q1 & 1 & 1 \\
\hline $\begin{array}{c}\text { Maximum } \\
\text { Value } \\
(\$)\end{array}$ & 1997Q3 & 2.796 & & 2007Q1 & & 2.656 \\
\hline $\begin{array}{l}\text { Maximum } \\
\text { Value } \\
(\$)\end{array}$ & 2007Q1 & & 13.520 & 2008Q2 & 3.875 & \\
\hline $\begin{array}{l}\text { Portfolio's } \\
\text { Value at } \\
\text { the End of } \\
\text { the } \\
\text { Analysis } \\
\text { Period } \\
\text { (\$) }\end{array}$ & 2009Q4 & 1.500 & 7.136 & 2009Q4 & 2.675 & 1.669 \\
\hline
\end{tabular}

Table 3 also shows the maximum value that each portfolio reaches during the study period. The REW portfolio reaches a maximum value of 2.796 in 1997Q3. The NEW portfolio reaches a maximum of 13.520 in 2007 Q1. The RVW portfolio reaches a maximum value of 3.875 in 2008Q2. The NVW portfolio reaches a maximum value of 2.656 in 2007Q1. 
Figures 3 and 4 show the historical cumulative return performance of all portfolios. Consistent with earlier findings, in equally-weighted portfolios, the restricted portfolio always underperformed the non-restricted one. In value-weighted portfolios, the restricted portfolio always outperformed the non-restricted one.

Figure 3 - Historical Performance of Equally-weighted Portfolios

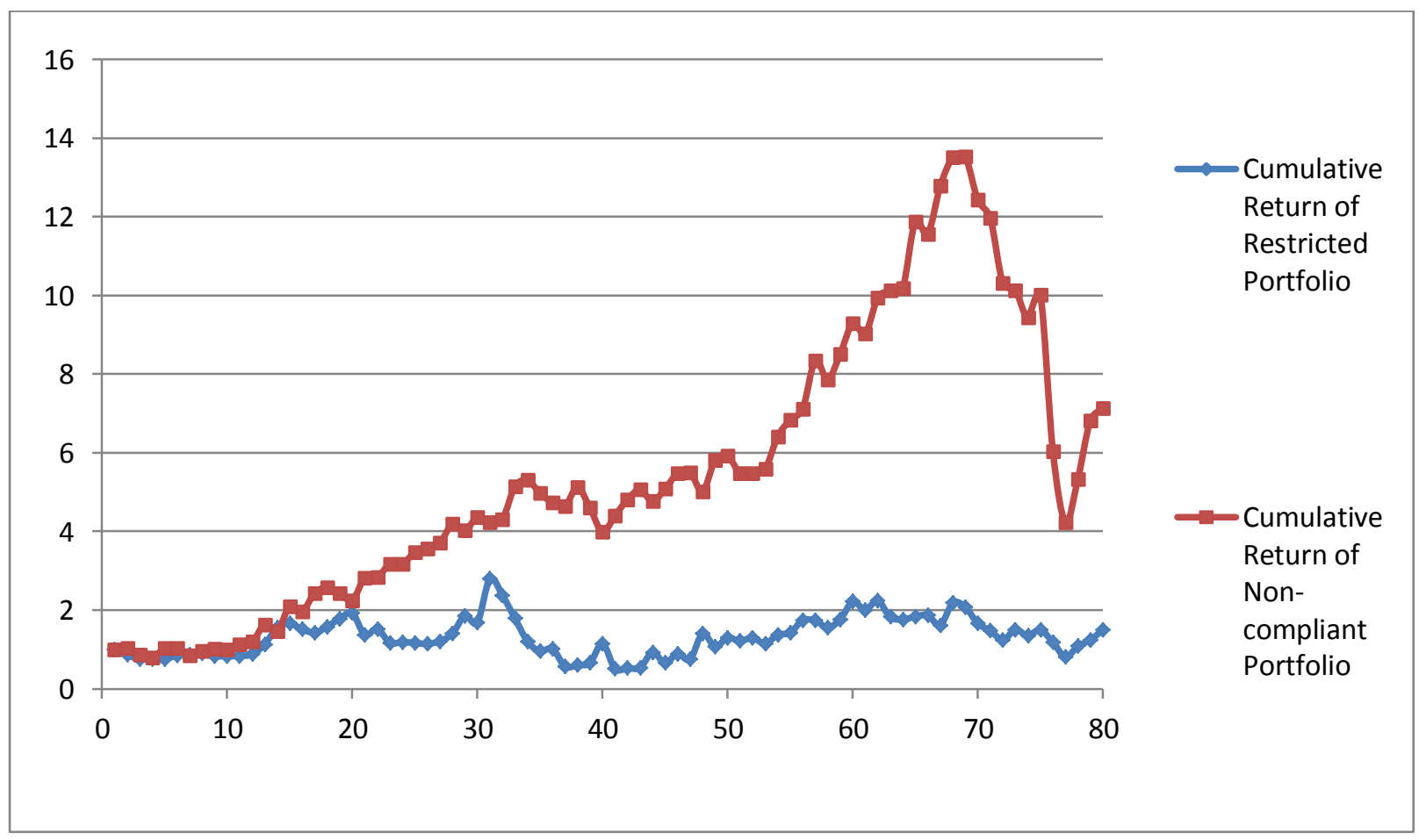

Starting with an initial investment of $\$ 1$, the graph shows the value of each portflio over time. The blue line represents the cumultive return of the constrained portfolio (Shariahcompliant REITs), REW. The red line represents the cumultive return of the non-constrained portfolio (all but the Shariah-compliant REITs), NEW. 
Figure 4 - Historical Performance of Value-weighted Portfolios

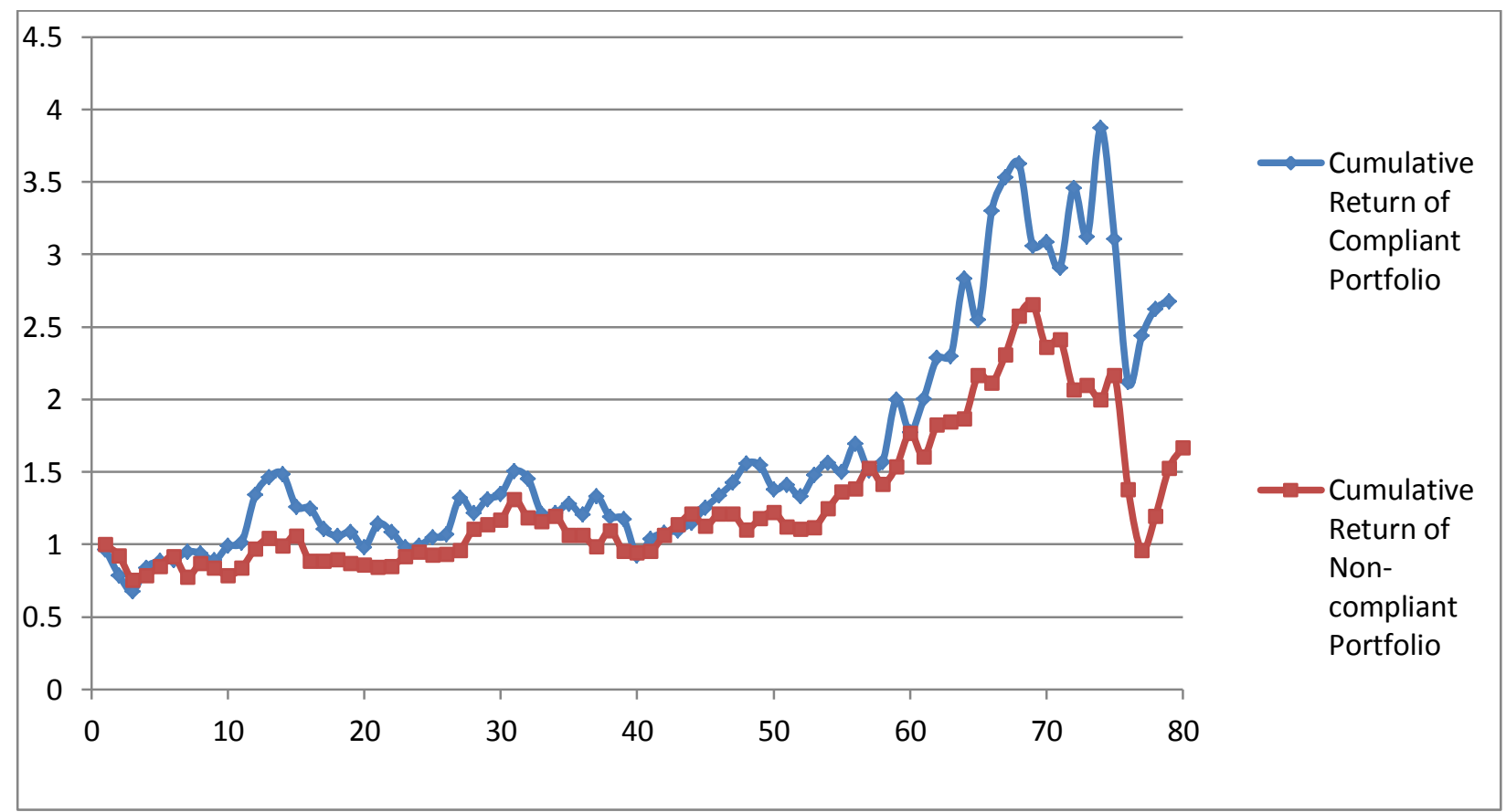

The blue line represents the cumultive return of the constraint portfolio (Shariahcompliant REITs), RVW. The red line represents the cumultive return of the non-constraint portfolio (all but the Shariah-compliant REITs), NVW.

Looking at the figures above, we notice that during the last five quarters of analysis, the performance of the portfolios seems to have a different pattern. This period covers the time of the financial crisis and recession. We notice that all four portfolios witnessed losses, as expected. To have a closer look at this period, we run separate analysis. This time we assume that our investor starts her investment in the beginning of 2008. She puts $\$ 1$ in each portfolio and follows the same re-balancing policy described above. The results are interesting. The Shariah-complaint restricted portfolio seems to offer better investment in both equal-weighting and value-weighting schemes. Results are reported in table 4 below. 
Table 4 Performance of Portfolios Measured by Value (2008Q1-2009Q4)

\begin{tabular}{c|cc|cc} 
& \multicolumn{2}{|c|}{ Equally-weighted Portfolio } & \multicolumn{2}{c}{ Value-weighted Portfolio } \\
\hline & $\begin{array}{c}\text { Restricted } \\
\text { Portfolio }\end{array}$ & $\begin{array}{c}\text { Non- } \\
\text { restricted } \\
\text { Portfolio }\end{array}$ & $\begin{array}{c}\text { Restricted } \\
\text { Portfolio }\end{array}$ & $\begin{array}{c}\text { Non- } \\
\text { restricted } \\
\text { Portfolio }\end{array}$ \\
\hline & REW & NEW & RVW & NVW \\
\hline Beginning of 2008 & 1 & 1 & 1 & 1 \\
\hline 2008Q1 & 1.209495902 & 0.982744098 & 1.188792467 & 1.013715982 \\
\hline 2008Q2 & 1.092824485 & 0.915163841 & 1.074108243 & 0.96518108 \\
\hline $2008 Q 3$ & 1.205816275 & 0.971639038 & 1.331509588 & 1.04745945 \\
\hline $2008 Q 4$ & 0.956656528 & 0.58613838 & 1.067943051 & 0.667741277 \\
\hline $2009 Q 1$ & 0.653777622 & 0.409896625 & 0.727778192 & 0.463140732 \\
\hline $2009 Q 2$ & 0.872248999 & 0.517120948 & 0.837908437 & 0.57755785 \\
\hline $2009 Q 3$ & 1.000526336 & 0.661610577 & 0.901909793 & 0.737575495 \\
\hline $2009 Q 4$ & 1.210755222 & 0.692053579 & 0.919090747 & 0.806414578 \\
\hline & & & &
\end{tabular}
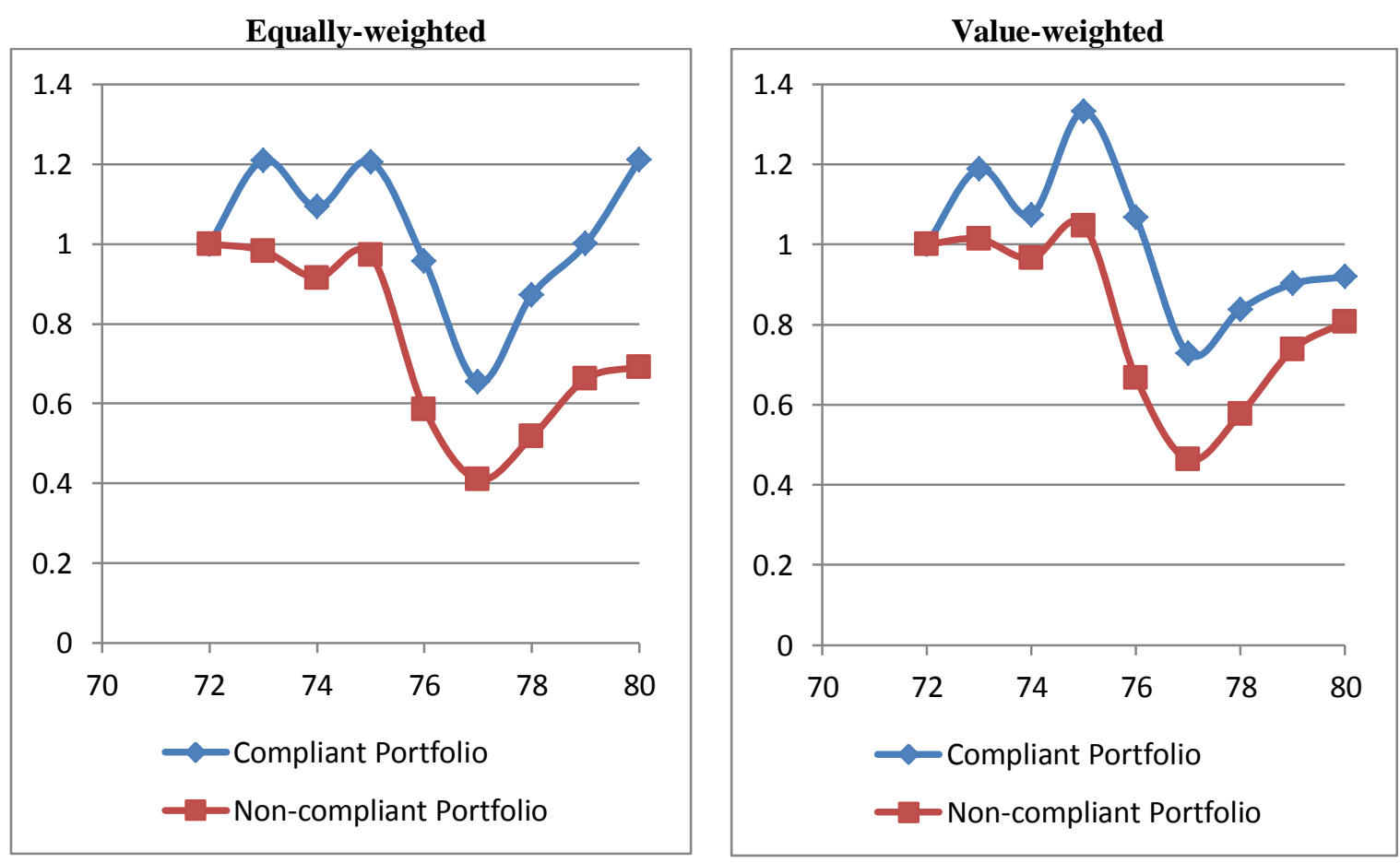

A dollar invested in the beginning of 2008 in REW (NEW) would become \$1.211 (\$0.692) by the end of 2009. Obviously, the difference is large and meaningful. The Shariah-compliant restricted portfolio ends with a gain of about 21 percent in two years during the crisis period when the non-Shariah restricted portfolio ends with a loss of about 31 percent of its value. With 
the value-weighted portfolios, both restricted and non-restricted portfolios show a loss. However, the restricted portfolio lost only 9 percent of its value while the non-restricted portfolio lost about 19 percent of its value.

\section{ii)}

We compute Jensen's alpha (Jensen 1968) of the Shariah compliant portfolios and compare it to Jensen's alpha of the non-compliant portfolio. If "alpha" is statistically significant and positive (negative), the portfolio is comprised of outperforming (underperforming) REITs. We start with the simple single-factor CAPM model. We run,

$$
R_{i t}-R_{f t}=\alpha_{i}+\beta_{i}\left(R_{m t}-R_{f t}\right)+\varepsilon_{i t}
$$

Where

$\begin{array}{lll}R_{i t} & : & \text { Return of portfolio } i \text { over period } t \\ R_{f t} & : & \text { Risk-free return rate } \\ R_{m t}-R_{f t} & : & \text { Excess return on the market portfolio for period } t \\ \beta_{i} & : & \text { Beta of portfolio } i \\ \alpha_{i} & : & \text { Jensen's alpha of portfolio } i\end{array}$

Since this analysis requires use of a market portfolio that is mostly available in monthly (not quarterly) frequency, we slightly change our way of tracking portfolios illustrated above. We still assume that our investor updates her portfolios every quarter (the highest frequency of data available in Compustat). However, we track each REIT on a monthly basis. Specifically, after we determine that a certain REIT complies (does not comply) with our selection criterion and thus is included in the compliant (non-complaint) portfolio, we track its performance on a monthly basis until the next quarter. We obtain its monthly market price from CRSP and, thus, obtain monthly values of our portfolios over the period March 1990 to December 2009. As a result, we are able to obtain monthly returns of our four portfolios during April 1990 to 
December 2009. These monthly returns are used in calculating Jensen's alpha in the rest of this paper. $^{13}$

We estimate the model above with monthly returns of all four portfolios REW, NEW, RVW, and NVW. We use several proxies of monthly returns of market portfolio including the monthly returns of the S\&P Composite Index (from CRSP), CRSP all-securities value-weighted market index (from CRSP), Nasdaq composite index, FTSE NAREIT U.S. Real Estate Index (from the NAREIT website, www.reit.com) and Fama-French's returns on the market (from CRSP). Risk free rate is proxied by the one-month Treasury Bill rate. Table 5 shows estimated values of slopes, Jensen's alpha, and other regression statistics for the four portfolios with each proxy of market returns.

\footnotetext{
${ }^{13}$ We repeat the analysis of average period returns and cumulative returns with quarterly data. We do not find any significant difference from the results obtained with monthly data. In fact, the overall conclusions are identical to those illustrated before with monthly data. We chose not to report these results for brevity, but they are available upon request.
} 


\section{Table 5 Jensen's Alpha of Portfolios under Different Criteria}

We regress portfolios' monthly returns on market benchmark using CAPM: $R_{i t}-R_{f t}=\alpha_{i}+\beta_{i}\left(R_{m t}-R_{f t}\right)+\varepsilon_{i t}$; we use several proxies for market benchmark. The slope $\beta_{\mathrm{i}}$ indicates portfolioi's relative risk as measured by co-variation between its monthly returns and the return on a perfectly diversified portfolio (market portfolio returns). The intercept $\mathrm{a}_{\mathrm{i}}$ captures excess average gain (loss) that investors realize by choosing to invest in portfolio $i$. A positive (negative) $\mathrm{a}_{\mathrm{i}}$ indicates that portfolio $i$ offers, on average, higher (lower) risk compensation than offered in the market. The table shows the estimated magnitude of regressions coefficients and their t-stat in parenthesis next to each coefficient.

\begin{tabular}{|c|c|c|c|c|c|}
\hline & & \multicolumn{2}{|c|}{ Equally-weighted Portfolio } & \multicolumn{2}{|c|}{ Value-weighted Portfolio } \\
\hline $\begin{array}{c}\text { Proxy of Perfectly Diversified } \\
\text { Portfolio (Market Portfolio) }\end{array}$ & & $\begin{array}{c}\text { Restricted Portfolio } \\
\text { REW } \\
\end{array}$ & $\begin{array}{c}\text { Non-restricted Portfolio } \\
\text { NEW }\end{array}$ & $\begin{array}{c}\text { Restricted Portfolio } \\
\text { RVW } \\
\end{array}$ & $\begin{array}{c}\text { Non-restricted Portfolio } \\
\text { NVW }\end{array}$ \\
\hline \multirow{3}{*}{ S\&P Market Return } & $\alpha$ & $.006076(1.15)$ & $.006478 * *(2.34)$ & $.002602(0.98)$ & $-.000442(-0.20)$ \\
\hline & $\beta$ & $.286637 * *(2.36)$ & $.270461 * * *(4.26)$ & $.180891 * * *(2.97)$ & $.251072 * * *(4.96)$ \\
\hline & $R^{2}$ & .023203 & .071542 & .036214 & .094887 \\
\hline \multirow{3}{*}{$\begin{array}{l}\text { CRSP All-securities Value- } \\
\text { weighted Return }\end{array}$} & $\alpha$ & $.005262(0.99)$ & $.005939 * *(2.14)$ & $.002255(0.85)$ & $-.000971(-.44)$ \\
\hline & $\beta$ & $.313923 * * *(2.69)$ & $.267754 * * *(4.38)$ & $.177333 * * *(3.02)$ & $.252126 * * *(5.19)$ \\
\hline & $R^{2}$ & .029902 & .075335 & .037394 & .102806 \\
\hline \multirow{3}{*}{$\begin{array}{l}\text { NASDAQ Composite } \\
\text { Index }\end{array}$} & $\alpha$ & $.006231(1.18)$ & $.007071 * *(2.50)$ & $.003000(1.12)$ & $.000098(0.04)$ \\
\hline & $\beta$ & $.164271 * *(2.19)$ & $.107856 * * *(2.69)$ & $.071955 *(1.89)$ & $.101278 * * *(3.15)$ \\
\hline & $R^{2}$ & .020005 & .029866 & .015042 & .040530 \\
\hline \multirow{3}{*}{$\begin{array}{l}\text { FTSE NAREIT U.S. Real } \\
\text { Estate Index }\end{array}$} & $\alpha$ & $.004445(.85)$ & $.004585 *(1.80)$ & $.000665(.27)$ & $-.002190(-1.12)$ \\
\hline & $\beta$ & $.364705 * * *(3.83)$ & $.382853 * * *(8.25)$ & $.329190 * * *(7.37)$ & $.354389 * * *(9.94)$ \\
\hline & $R^{2}$ & .058800 & .224402 & .187739 & .295926 \\
\hline \multirow{3}{*}{$\begin{array}{l}\text { Fama-French Market } \\
\text { Return }\end{array}$} & $\alpha$ & $.006193(1.18)$ & $.006752 * *(2.45)$ & $.002789(1.06)$ & $-.002061(-.09)$ \\
\hline & $\beta$ & $.323027 * * *(2.77)$ & $.271665 * * *(4.44)$ & $.180770 * * *(3.079)$ & $.255936 * * *(5.27)$ \\
\hline & $R^{2}$ & .031591 & .077380 & .038771 & .105702 \\
\hline
\end{tabular}


All betas are positive and statistically significant in all four portfolios and with all market proxies. Understandably, they are higher when NAREIT is used and lower when NASDAQ is used as proxy of market return. This is simply because the NAREIT contains REITs only while the NASDAQ index includes technology stocks that fluctuate, in aggregate, for causes different from those of the real estate sectors.

The positive beta is loosely interpreted as evidence that the portfolio "follows" the market. This indicates a positive correlation between our REIT portfolios' return and market return. However, all betas' magnitudes are relatively smaller than 1 . Hence, all of our portfolios are generally deemed as less volatile than the market portfolio. Yet, in equally-weighted portfolios, betas of restricted portfolios are generally higher (in all five proxies of market return except NAREIT) than the betas of the unrestricted portfolio. The inverse observation is found in value-weighted portfolios (in all five proxies of market return). We conclude that the Shariah constraint value-weighted portfolio of REITs is less volatile than the non-constrained ones.

We find that all alphas are statistically insignificant in REW portfolios, except in NEW portfolios whey they are positive and significant. A restricted portfolio is not generating any excess return, while a non-restricted portfolio generates excess return of about $65,59,70,46$, and 67 basis points per month depending on which proxy is used. This is equivalent to about 7.8 percent, 7.08 percent, 8.4 percent, 5.52 percent, and 8.04 percent annual excess return depending on which market proxy is used. This is also in line with our earlier findings (derived from average period return and cumulative return) that in equally-weighted portfolios non-constrained REITs outperform the constrained ones. We also find that all alphas are statistically insignificant in RVW and NVW portfolios. This is slightly different from our earlier findings derived from 
average period return and cumulative return. There seems to be no difference between restricted and non-restricted REITs in value-weighted portfolios.

\section{iii) Extended Asset Pricing Models}

We start with Fama and French (1993 and 1996) three-factor model:

$$
R_{i t}-R_{f t}=\alpha_{i}+\beta_{i, 1}\left(R_{m t}-R_{f t}\right)+\beta_{i, 2} H M L+\beta_{i, 3} S M B+\varepsilon_{i t}
$$

$\begin{array}{lll}\text { Where } & & \\ R_{i t} & : & \text { Return of portfolio } i \text { over period } t \\ R_{f t} & : & \text { Risk-free return rate (Ibbotson one-month Treasury Bill rate) } \\ R_{m t}-R_{f t} & : & \text { Excess return on the market for period } t \\ \beta_{i, j} & : & \text { Beta of portfolio } i \text { of factor } j \\ \text { HML } & : & \begin{array}{l}\text { Difference in return between a portfolio of high book-to-market stocks } \\ \text { and one of low book-to-market stocks at time } t\end{array} \\ \text { SMB } & : & \begin{array}{l}\text { Difference in return between a small cap portfolio and a large cap } \\ \text { portfolio at time } t\end{array} \\ \varepsilon_{i t} & : & \begin{array}{l}\text { Random error term for REIT } i \text { over period } t \text { with an expected value of } \\ \text { zero. }\end{array}\end{array}$

Carhart (1997) extends CAPM by including Fama and French (1993 and 1996) factors, and a momentum factor of Jegadeesh and Titman (1993). The resulting model is a 4-factor market equilibrium model, where the coefficients provide indication of the style focus of a portfolio. This model is formally described as follows:

$$
R_{i t}-R_{f t}=\alpha_{i}+\beta_{i, 1}\left(R_{m t}-R_{f t}\right)+\beta_{i, 2} H M L+\beta_{i, 3} S M B+\beta_{i, 4} M O M+\varepsilon_{i t}
$$

Where

MOM
Difference in return between a portfolio of past 12 month winners and a portfolio of past 12 month losers at time $t$

Results are shown in table 6. 
Table 6 Jensen's Alpha of Portfolios Using the Three-factor and Four-factor Models

\begin{tabular}{c|cc|cc|}
\multirow{4}{*}{} & \multicolumn{2}{|c|}{ Equally-weighted Portfolio } & \multicolumn{2}{c|}{ Value-weighted Portfolio } \\
\cline { 2 - 5 } & $\begin{array}{c}\text { Restricted } \\
\text { Portfolio } \\
\text { REW }\end{array}$ & $\begin{array}{c}\text { Non-restricted } \\
\text { Portfolio } \\
\text { NEW }\end{array}$ & Restricted Portfolio & $\begin{array}{c}\text { Non-restricted } \\
\text { Portfolio }\end{array}$ \\
\cline { 2 - 5 } & \multicolumn{4}{|c|}{ Panel A - Three-factor Model } \\
NVW
\end{tabular}

We regress portfolio returns on market return, book-to-market factor, size factor using threefactor model (Panel A):

$$
R_{i t}-R_{f t}=\alpha_{i}+\beta_{i, 1}\left(R_{m t}-R_{f t}\right)+\beta_{i, 2} H M L+\beta_{i, 3} S M B+\varepsilon_{i t}
$$

Then, we regress portfolio returns on market return, book-to-market factor, size factor and momentum factor using four-factor model (Panel B):

$$
R_{i t}-R_{f t}=\alpha_{i}+\beta_{i, 1}\left(R_{m t}-R_{f t}\right)+\beta_{i, 2} H M L+\beta_{i, 3} S M B+\beta_{i, 4} M O M+\varepsilon_{i t}
$$

The table shows that alphas are statistically insignificant whether we use equally-weighted or value-weighted portfolios. This finding does not change whether we use a three-factor model (Panel A) or four-factor model (Panel B). Consistent with Ibrahim and Ong (2008), we conclude that when other risk factors are controlled for, there is no convincing evidence that the restricted portfolio's performance differs from the non-restricted one. Since betas are all significant (and 
positive) in all four regressions, we conclude that market-wide risk-return characteristics are more important than compliance vs. non-compliance characteristics. In other words, although we have shown that a compliant portfolio outperforms a non-compliant one, the difference becomes insignificant when we control for broad economic factors. In practical terms, investors who invest exclusively in REIT securities make a higher return if they choose to invest in debtconservative REITs. This is not true for investors with more diversified portfolios.

\section{Conclusions}

We adopt the research design of Ibrahim and Ong (2008), who conduct an experiment to evaluate the performance of Shariah-compliant REITs using operational but not financial screening. They find evidence that restricted portfolios underperform the non-restricted ones and the benchmarks on both equal- and value-weighted portfolios. They find less profound results with other measures of performance. They conclude that there is no evidence of Shariahcompliant REITs' underperformance when they control for other risk factors.

We collect quarterly data on 163 active REIT's (CIS code 6798) from Compustat databases over the period 1990Q1-2009Q4 (there are 80 quarters). We create a restricted REIT (Shariahcompliant) and a non-restricted REIT (Shariah non-compliant) portfolio based with equalweighting and value-weighting. Our filtering threshold is a maximum of 33 percent debt ratio permitted by Shariah investing principles. For the purpose of comparison, we form two nonrestricted portfolios (one equally-weighted and one value-weighted) composed of all the REITs that do not pass as compliant.

In contrast with Ibrahim and Ong (2008), we find the restricted portfolio performs better in value-weighting (but not in equal-weighting) in both average return and volatility. The BHR 
analysis reveals similar results. The restricted equally-weighted portfolio always underperformed the non-restricted one, while the restricted value-weighted portfolio always outperformed the non-restricted one. During the recent crisis period, however, the restricted portfolio outperformed the non-restricted one under both equally-weighting and value-weighting schemes. The restricted equally-weighted portfolio generated a gain of about 21 percent in two years during the crisis period when the non-restricted portfolio ended with a loss of about 31 percent of its value. The restricted value-weighted portfolio lost only 9 percent of its value while the non-restricted portfolio lost about 19 percent of its value in two years during the crisis period.

We compute Jensen's alpha of all four portfolios using several proxies of monthly market return. We use the one-month Treasury Bill rate as a proxy for the risk-free rate. We find that the constrained value-weighted portfolio of REITs is less volatile than the non-constrained one. Again we find that in equally-weighted portfolios, non-constrained REITs outperform the constrained ones. However, there seems to be no difference between restricted and non-restricted REITs in value-weighted portfolios. Finally, we use the Fama and French (1993 and 1996) threefactor model and the Carhart (1997) four-factor market equilibrium model. We find that when other risk factors are controlled for, there is no convincing evidence that the restricted portfolio's performance differs from the non-restricted one [consistent with Ibrahim and Ong (2008)] and that market-wide risk-return characteristics are more important than compliance vs. noncompliance characteristics.

In summary, Ibrahim and Ong (2008) apply operational screening and find inconclusive results that generally lean toward better performance of non-restricted portfolios. We use financial screening and also find inconclusive results. Our results, however, are more in favor of 
the restricted portfolio. We obtain somewhat firm indications that restricted portfolios perform better during a financial crisis. Such findings call for more research in this topic. 


\section{References}

Abdul Halim, Abdul Hamid and Norizaton Azmin, Mohd Nordin, 2001, “A study on Islamic banking education and strategy for the new millennium: Malaysian experience," International Journal of Islamic Financial Services, 2(4), 3-11.

Aggarwal, Rajesh K. and Tarik Yousef, 2000, "Islamic banks and investment financing," Journal of Money, Credit and Banking, 32(1) 93-120.

Bauer, Rob, Rogér Otten and Alireza Tourani Rad, 2006, "Ethical investing in Australia: Is there a financial penalty?," Pacific-Basin Finance Journal, 14(1), 33-48.

Bauer, Rob, Kees Koedijk, and Rogér Otten, 2005, “International evidence on ethical mutual fund performance and investment style," Journal of Banking andFinance, 29(7), 17511767.

Carhart, M., 1997. “On persistence in mutual fund performance,” Journal of Finance, 52(1), 5782.

Chan, S. H., Leung, W.-K., \& Wang, K. (2005). "Changes in REIT structure and stock performance: Evidence form the Monday stock anomaly," Real Estate Economics, 33(1), 89-120.

Chow, C., 2006, “City and Country: Recycling Petro Dollars,” The Edge, September 18.

Dusuki, A. W., (2007). Practice and Prospect of Islamic Real Estate Investment Trusts (I-REITs) in Malaysian Islamic Capital Market. Paper Presented at The International Conference on Islamic Capital Markets organized by Islamic Research and Training Institute (IRTI), Islamic Development Bank, 27th - 29th August 2007, Jakarta. 
Elfakhani, S., Hassan, M. K. \& Sidani, Y., 2005, “Comparative performance of Islamic versus secular mutual funds," Paper presented at the 12th Economic Research Forum Conference in Cairo, Egypt, on December 19-21.

El-Gamal, M. Amin, 2000, "A basic guide to contemporary Islamic banking and finance," http://www.ruf.rice.edu/ elgamal/files/primer.pdf, accessed September 24, 2009.

Fama, Eugene and Kenneth French, 1993, "Common risk factors in the returns on stocks and bonds. Journal of Financial Economics, 33(1), 3-56.

Fama, Eugene and Kenneth French, 1995, "Size and Book-to-Market Factors in Earnings and Returns," Journal of Finance, 50(1), 131-155.

Fama, Eugene and Kenneth French, 1996a, "Multifactor Explanations of Asset Pricing Anomalies," Journal of Finance, 51(1), 55-84.

Fama, Eugene and Kenneth French, 1996b, “The CAPM is Wanted, Dead or Alive.” Journal of Finance, 51(5), 1947-1958.

Feng, Zhilan, Chinmoy Ghosh, and C. F. Sirmans, 2007, “On the Capital Structure of Real Estate Investment Trusts (REITs)," Journal of Real Estate Finance and Economics 34, 81-105.

Fikriyah Abdullah, Taufiq Hassan and Shamsher Mohamad Ramadilli Mohd, 2007, "Investigation of Performance of Malaysian Islamic Unit Trust Funds: Comparison with conventional Trust Performance," Managerial Finance, 33(2), 142-153.

Ghosh, Chinmoy, Raja Nag and C. F. Sirmans, 1999, “An Analysis of Seasoned Equity Offerings by Equity REITs, 1991 to 1995," Journal of Real Estate Finance and Economics, 19(3), 175.

Girard, Eric, Hamid Rahman and Brett Stone, 2007, "Socially Responsible Investments: GoodyTwo-Shoes or Bad to the Bone?," Journal of Investing, 16(1), 96-110. 
Girard, Eric and M. Kabir Hassan, 2008, "Is there a Cost to Faith-Based Investing? Evidence from FTSE Islamic Indices,” Journal of Investing, 17(4), 112-121.

Hakim, S. \& Rashidian, M.; 2004a; "Risk and return of Islamic stock market indexes.” Paper presented at the International Seminar of Non-bank Financial Institutions: Islamic Alternatives, Kuala Lumpur, Malaysia.

Hakim, S. \& Rashidian, M.; 2004b; “How costly is investor's compliance to Sharia?” Paper presented at the 11th Economic Research Forum Annual Conference in Sharjah, U.A.E. on December 14-16, Beirut, Lebanon.

Hassan, M. K. \& Tag el-Din, S.I.; 2005; "Speculative bubbles in Islamic stock market-empirical assessment." MIHE Working Paper, Leicester, U.K.

Hassan, M. Kabir, 2002, "Risk, return and volatility of faith-based investing: The case of the Dow Jones Islamic Index," Paper in Proceedings of 5th Harvard University Forum on Islamic Finance, Harvard University.

Hussein, K.; 2005; “Islamic investment: Evidence from Dow Jones and FTSE Indexes.” Paper presented at the 6th International Conference on Islamic Banking and Finance, Jakarta, Indonesia, November 21-14, 2005.

Ibrahim, M. F., \& Ong, S. E. (2008). Shariah Compliance in Real Estate Investment. Journal of Real Estate Portfolio Management, 14(4).

Jegadeesh, N. and Titman, S., 1993, Journal of Finance, Vol. 48 Issue 1, p65-91, 27p

Lin, C., \& Yung, K. (2006). Equity Capital Flows and Demand for REITs. Journal of Real Estate Financial Economics, Vol. 33 Issue 3, p275-291.

Orlitzky, Marc, Frank L. Schmidt and Sara L. Rynes, 2003, "Corporate Social and Financial Performance: A Meta-analysis," Organization Studies , 24(3), 403-441. 
Porter, M. E., and van der Line, C.; 1995; "Green and Competitive: Ending the Statement," Harvard Business Review, September/October, 120-135.

Schröder, M., 2004, “The Performance of Socially Responsible Investments: Investment Funds and Indices," Financial Markets and Portfolio Management, 18(2), 122-142.

Usmani, M.T., 2002, “An introduction to Islamic finance,” The Netherlands: Kluwer Law International.

Walley, N. and Whitehead, B.; 1994; "It's not easy being Green," Harvard Business Review, May/June, 46-52. 